\title{
Pengaturan Perlindungan Data Pribadi dalam Penggunaan Aplikasi PeduliLindungi
}

\author{
Nurhidayati $^{1}$, Sugiyah ${ }^{2}$, Kartika Yuliantari ${ }^{3}$ \\ 1,2,3 Universitas Bina Sarana Informatika \\ Jl. Kramat Raya No 98, Senen, Jakarta Pusat, Indonesia
}

e-mail: ${ }^{1}$ nurhidayati.nht@ bsi.ac.id, ${ }^{2}$ sugiyah.sgy@bsi.ac.id, ${ }^{3}$ kartika.kkj@bsi.ac.id

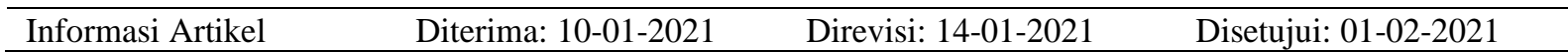

\begin{abstract}
Abstrak
Pandemi covid-19 sudah berlangsung selama 9 bulan, dengan jumlah yang terpapar terus meningkat. Berbagai upaya dilakukan pemerintah untuk mengurangi penyebaran wabah tersebut, salah satunya dengan meluncurkan Aplikasi PeduliLindungi. PeduliLindungi ditetapkan sebagai aplikasi yang membantu melakukan Tracing, Tracking, Fancing melalui infrastruktur, sistem dan aplikasi telekomunikasi yang terhubung dengan data center dalam negeri. Penelitian ini bertujuan untuk mengetahui perlindungan data pribadi bagi pengguna Aplikasi PeduliLindungi. Metode Penelitian melalui studi literatur, dengan data sekunder, menggunakan bahan hukum primer, sekunder, tersier, dengan mengkaji berbagai peraturan, mengingat sampai saat ini belum ada undangundang yang mengatur tentang perlindungan data pribadi. Hasil penelitian menunjukkan Perlindungan data pribadi pengguna aplikasi ini didasarkan pada peraturan yang mengatur tentang Teknologi Informasi dan Komunikasi, Kesehatan, dan Pelaksanaan administrasi Kependudukan, meskipun pemerintah memberikan jaminan keamanan bagi pengguna PeduliLindungi, namun sampai saat ini pengguna aplikasi PeduliLindungi masih kurang diminati. Harapan kedepannya semakin banyak yang mengunduh PeduliLindungii, sehingga dapat menekan angka penyebaran covid-19. Selain itu pentingnya segera disahkan undang-undang perlindungan data pribadi untuk memberikan kepastian hukum.
\end{abstract}

Kata Kunci: Perlindungan, Data Pribadi, Aplikasi, TIK

\begin{abstract}
The Covid-19 pandemic has been going on for 9 months, with the number exposed to continue to increase. Various efforts have been made by the government to reduce the spread of the epidemic, one of which is by launching the PeduliLindungi application. PeduliLindungi is designated as an application that helps carry out tracing, tracking, fancing through telecommunications infrastructure, systems and applications connected to domestic data centers. This study aims to determine the personal data protection for users of the PeduliLindungi application, through literature studies, with secondary data, using primary and secondary legal materials by examining various regulations related to personal data protection, considering that until now there is no law regulating the protection of personal data. . Protection of personal data related to the use of this application is based on regulations governing Information and Communication Technology, Health and Population administration, although the government provides security guarantees for PeduliLindungi users, but until now, users of the PeduliLindungi application are still not in demand. It is hoped that in the future more and more people will download PeduliLindungi, so that they can reduce the number of the spread of covid-19. In addition, it is important to immediately pass a personal data protection law to provide legal certainty.
\end{abstract}

Keywords: Protection, Personal Data, Applications, ICT

\section{Pendahuluan}

Awal mula wabah covid-19 berasal dari Wuhan sebuah kota di Propinsi Hubei Tiongkok. Virus itu kemudian menyebar ke negara negara di benua Amerika, Eropa dan Asia. Hal ini menjadi perhatian yang sangat serius, organisasi kesehatan dunia (WHO), sehingga menetapkan COVID-19 sebagai pandemi global (11 Maret 2020) dan setiap negara dianjurkan untuk meningkatkan respon darurat.

Di Indonesia ditemukan pertama kali kasus virus covid-19 tanggal 2 Maret 2020, kurang lebih 61 hari dari kasus pertama di Tiongkok. Pemerintah melalui Badan Nasional Penanggulangan Bencana (BNPB) telah menetapkan Status Keadaan Tertentu Darurat Bencana Wabah Penyakit akibat Virus Corona di Indonesia melalui SK Kepala BNPB 
Nomor 9.A. tahun 2020, selain itu Presiden Joko Widodo menetapkan Keppres No. 11 Tahun 2020 tentang Penetapan Kedaruratan Kesehatan Masyarakat Covid-19, tanggal 31 Maret 2020. dan Keppres No. 12 Tahun 2020 tentang Penetapan Bencana Non alam Penyebaran COVID-19 sebagai bencana nasional, tanggal 13 April 2020.

Merebaknya pandemi Covid-19 di berbagai negara telah menyebabkan krisis global, baik dibidang ekonomi maupun kemanusiaan. Krisis kemanusiaan terjadi dengan banyaknya korban terinfeksi maupun meninggal dunia, yang mencapai jutaan jiwa di seluruh dunia dan kemungkinan akan terus bertambah mengingat sampai sekarang pandemi belum dapat dipastikan kapan akan berakhir. Disatu sisi vaksin untuk menangkal virus masih diuji cobakan, karena itu penanganan akibat krisis ini harus ditangani dengan cara-cara yang cepat dan tepat.

Adanya pandemi ini sudah merubah pola kehidupan masyarakat di berbagai bidang. Pola kegiatan masyarakat yang awalnya banyak di lapangan sekarang mulai dilakukan dengan menggunakan digitalisasi. Penggunaan teknologi informatika dan komunikasi menjadi hal yang mutlak dibutuhkan dalam suasana pandemi, karena sebagian masyarakat harus melakukan Work From Home (WFH). Untuk meminimalisir penyebaran covid-19 pemerintah melakukan imbauan untuk selalu menjaga jarak fisik (physical distancing), dengan menjauhi kerumunan, menghindari pertemuan massal, kerja dari rumah, belajar, hingga beribadah di rumah.

Dalam rangka mengatasi penyebaran Covid19, Menteri Komunikasi dan Informatika berdasarkan Keputusan Menteri Komunikasi dan Informatika nomor 171 Tahun 2020, telah membuat Aplikasi PeduliLindungi untuk mendukung surveilans kesehatan, melengkapi Keputusan Menteri Komunikasi dan Informatika Nomor 159 Tahun 2019, tentang Upaya Penanganan virus desease (Covid-19) melalui dukungan sektor Pos dan Informatika. Aplikasi ini akan membantu instansi pemerintah terkait dalam melakukan pelacakan dalam rangka menghentikan penyebaran Coronavirus Disease (COVID-19). Penggunaan aplikasi ini akan berhubungan dengan data pengguna dan pengelola/penyelenggara aplikasi tersebut, karena itu dalam penelitian ini akan membahas perlindungan data pribadi sehubungan dengan penggunaan Aplikasi PeduliLindungi. Penelitian ini merupakan penelitian terbaru karena aplikasi PeduliLindungi baru diresmikan tahun 2020. Dimana perlindungan terhadap pengguna aplikasi ini tersebar diberbagai peraturan. Penelitian sebelumnya antara lain membahas perlindungan privasi dan data pribadi dalam era ekonomi digital di Indonesia, (Rosadi, 2018), artikel ini membahas perlunya adanya persyaratan instrumen hukum dalam perlindungan data pribadi. Sedangkan penelitian yang dilakukan
(Dewi, 2016). Membahas pentingnya perlindungan data pribadi pengguna cloud computing terlindungi dari berbagai macam pengungkapan dan pendistribusian oleh penyedia jasa cloud computing.terhadap pihak ketiga.

Di era revolusi digital saat ini data pribadi merupakan aset yang sangat berharga dan memiliki nilai yang tinggi, karena itu perlindungan terhadap data pribadi menjadi sangat penting mengingat berbagai aktivitas dalam kehidupan masyarakat sudah banyak yang menggunakan teknologi informasi. Apalagi saat pandemi Covid-19, penggunaan teknologi digital meningkat tajam, padaD aplikasi jual beli daring dan pembayaran daring. Penggunaan jual beli daring meningkat 73 persen, sedangkan pembayaran daring meningkat 65 persen. (Sumitra, 2020). Undang-Undang yang pertama kali mengatur tentang pemanfaatan teknologi informasi dan transaksi elektronik adalah UU Nomor 11 Tahun 2008. Kemudian dibuat Peraturan Pelaksana dari Undang-Undang ini yaitu Peraturan Pemerintah No. 82 Tahun 2012 yang mengatur perlindungan data pribadi yang harus dilakukan penyelenggara sistem elektronik. Dalam implementasinya Undang-Undang ini mengalami uji materi beberapa kali di Mahkamah Konstitusi. Kemudian Undang-Undang ini mengalami perubahan dan lahirlah UU No. 19 Tahun 2016 tentang Informasi dan Transaksi Elektronik.

Suatu data adalah data pribadi apabila data tersebut berhubungan dengan seseorang, sehingga dapat digunakan untuk mengidentifikasi orang tersebut, yaitu pemilik data (Europe, 2014). Data Pribadi adalah data perseorangan tertentu yang disimpan, dirawat, dan dijaga kebenaran serta dilindungi kerahasiaannya. (Peraturan Menteri Komunikasi dan Informatika No. 20 Tahun 2016 Tentang Perlindungan Data Pribadi Dalam Sistem Elektronik, 2016). Selain itu juga diartikan setiap data tentang seseorang baik yang teridentifikasi dan/atau dapat diidentifikasi secara tersendiri atau dikombinasi dengan informasi lainnya baik secara langsung maupun tidak langsung melalui Sistem Elektronik dan /atau nonelektronik. (Peraturan Pemerintah No.71 Tahun 2019 Tentang Penyelenggaraan Sistem dan Transaksi Elektronik, 2019).

Perlindungan data pribadi merupakan hak pribadi yang mencakup hak menikmati kehidupan pribadi dan bebas dari segala macam gangguan, Hak berkomunikasi dengan orang lain tanpa bermaksud memata matai, dan hak mengawasi akses informasi tentang kehidupan pribadi dan data seseorang. Penjelasan 26 ayat 1 (Undang-Undang No.19 Tahun 2016, 2016).

Indonesia mengenal hak pribadi sejak diberlakukannya KUHPerdata oleh pemerintah kolonial Belanda, yaitu adanya konsep larangan memasuki rumah atau pekarangan orang tanpa izin. Data pribadi merupakan hak konstitusional warga 
negara dan ini tercantum dalam UUD 1945 bab XA Pasal 28 G. Dalam Pasal tersebut menunjukkan bahwa setiap orang berhak atas perlindungan diri...., berhak atas rasa aman dan bebas dari ancaman, ketakutan, untuk berbuat atau tidak berbuat sesuatu yang merupakan hak asasi. Sejalan dengan itu di dalam (Undang-Undang No. 39 Tahun 1999 Tentang Hak Asasi Manusia, 1999) ada beberapa pasal yang menjamin perlindungan hak pribadi seperti dalam Pasal 14 (2) "Setiap orang berhak untuk mencari, memperoleh, memiliki, menyimpan, mengolah, dan menyampaikan informasi dengan menggunakan segala jenis sarana yang tersedia."Pasal 29 (1) menyebutkan "setiap orang berhak atas perlindungan diri pribadi, keluarga, kehormatan, martabat, dan hak miliknya. Sedangkan Pasal 32 menjelaskan bahwa .... hubungan komunikasi melalui sarana elektronik tidak boleh diganggu, merdeka dan rahasia kecuali atas perintah hakim atau kekuasaan lain yang sah sesuai dengan ketentuan peraturan perundangundangan. Selain itu, Indonesia juga menjadi salah satu pihak Kovenan Internasional tentang Hak hak Sipil dan Politik (International Covenant on Civil and Political Rights) yang telah disahkan melalui UU No.12 Tahun 2005.

Perlindungan Data Pribadi dalam Sistem Elektronik mencakup perlindungan terhadap perolehan, pengumpulan, pengolahan, penganalisisan, penyimpanan, penampilan, pengumuman, pengiriman, penyebarluasan, dan pemusnahan Data Pribadi.(Peraturan Menteri Komunikasi Dan Informatika No. 20 Tahun 2016 Tentang Perlindungan Data Pribadi Dalam Sistem Elektronik, 2016)

Dalam rangka mencegah penyebaran wabah covid-19 PT Telekomunikasi Indonesia Tbk, (Telkom) dan Kementerian Komunikasi dan Informatika (Kominfo) telah meluncurkan aplikasi PeduliLindungi. Aplikasi ini dikembangkan pemerintah untuk membantu pelacakan dalam rangka menghentikan penyebaran Coronavirus Disease (Covid-19).

\section{of Pedulitindungi}

Sumber: https://PeduliLindungi.id/

\section{Gambar 1. Logo PeduliLindungi}

PeduliLindungi sebagai Aplikasi yang dipergunakan dalam pelaksanaan surveilans kesehatan dalam menangani penyebaran covid-19, dengan menyelenggarakan Tracing yaitu, melakukan pelacakan terhadap orang-orang yang berkontak dengan orang orang yang diduga mengidap covid-19, selain itu juga Tracking yaitu melacak persebaran virus corona dengan melihat siapa saja yang telah bertemu dengan penderita virus corona dan menyelenggaraakan Warning and Fencing yaitu adanya peringatan dan pengawasan dengan membatasi pergerakan seseorang yang sedang dalam karantina atau isolasi. (Maulana, 2020). Penggunaan aplikasi PeduliLindungi dilakukan hanya pada masa darurat covid-19. Agar dapat melakukan penelusuran riwayat kontak dengan penderita covid-19, maka sangat dibutuhkan partisipasi masyarakat, dengan saling membagikan data lokasinya saat bepergian.

Aplikasi PeduliLindungi akan merekam data pergerakan pasien selama 14 hari terakhir, aplikasi terhubung dengan telepon seluler untuk menghasilkan visualisasi pergerakan, sistem aplikasi akan memberikan peringatan melalui ponsel orang orang disekitar pasien yang terdeteksi agar menjalankan protokol ODP (orang dalam pemantauan) (Kompas, 2020). Cara kerja PeduliLindungi dalam (K. K. Informatika, 2020)

a. Dimulai dengan mengunduh aplikasi PeduliLindungi. Pada saat mengunduh sistem ini maka akan meminta persetujuan pengguna untuk mengaktifkan data lokasi untuk memberi informasi terkait zonasi dan area karantina mandiri.

b.Dengan kondisi lokasi aktif, aplikasi akan melakukan identifikasi lokasi pengguna serta memberikan informasi terkait keramaian dan zonasi.

c. Hasil tracing ini akan memudahkan pemerintah untuk mengidentifikasi siapa saja yang perlu mendapat penanganan lebih lanjut agar penghentian penyebaran COVID-19 dapat dilakukan. Apabila banyak yang menggunakan aplikasi ini, maka akan semakin membantu pemerintah dalam melakukan tracing dan tracking.

PeduliLindungi akan memberikan notifikasi apabila:

a.Pengguna mengaktifkan PeduliLindungi dalam waktu yang cukup lama, di tempat yang sama dalam keramaian bersama pengguna lain.

b.Pengguna masuk ke zona tertentu:

1) Zona Merah menunjukkan sudah terdata ada kasus Covid-19 di area atau tempat tersebut

2) Zona Kuning menunjukkan sudah terdata ada Suspek Covid-19 pada area atau kelurahan tersebut.

3) Zona Hijau menunjukkan bahwa area atau kelurahan tersebut tidak ada kasus COVID-19 yang Terkonfirmasi, Suspek, atau Kontak Erat,

c.Pengguna berstatus dalam karantina mandiri, namun pengguna keluar dari zona karantina/ isolasi. Penggunaan aplikasi ini dapat melalui Android maupun IOS. Agar berfungsi maka PeduliLindungi harus selalu terbuka. Sumber informasi dan himbauan yang yang terdapat di aplikasi PeduliLindungi berasal dari Kementerian Kesehatan, Kementerian Kominfo, Situs Resmi COVID-19 Indonesia dan Organisasi Kesehatan Dunia (WHO). (K. K. Informatika, 2020)

\section{Metode Penelitian}

Penelitian ini bersifat deskriptif kualitatif melalui pendekatan yuridis normatif, melakukan analisis terkait dengan aturan yang ada. Pengumpulan 
data dilakukan melalui studi literatur untuk mencari data sekunder dengan menggunakan bahan hukum primer, sekunder dan tersier.

\section{Hasil dan Pembahasan}

3.1. Dasar Hukum PeduliLindungi Penanganan virus desease covid-19, didasarkan pada:

a. (Keputusan Menteri Komunikasi Dan Informatika No.159 Tahun 2020 Tentang Upaya Penanganan Corona Virus Disease (COVID-19) melalui Dukungan Sektor Pos Dan Informatika, 2020). yang menyebutkan bahwa penyelenggara telekomunikasi, Lembaga Penyiaran, Penyelenggara Media Daring dan Media lainnya serta Pos agar berkontribusi, menfasilitasi dan melakukan langkah-langkah dalam rangka membantu pemerintah mempercepat penanganan covid-19, yaitu dengan melakukan pemberian informasi dan data, penyediaan aplikasi, pemanfaatan Mobile Subscriber Integrated Services Digital Network Number (MSISDN), Short Massage service ke banyak tujuan (SMS Blast), penerapan standar kesehatan, keamanan dan keselamatan yang tinggi bagi pengiriman pos......dan lain lain.

b. (Keputusan Menteri Komunikasi Dan Informatika No. 171 Tahun 2020 Tentang Penetapan Aplikasi PeduliLindungi Dalam Rangka Pelaksanaan Surveilans Kesehatan Penanganan Covid-19, 2020) menyebutkan bahwa Aplikasi PeduliLindungi dikembangkan oleh PT Telekomunikasi Indonesia Tbk hak ciptanya dilisensikan secara eksklusif ke Pemerintah Indonesia cq Kementrian Komunikasi dan Informatika serta Kementrian Badan Usaha Milik Negara. Penggunaan AplikasiPeduliLindungi hanya pada masa darurat Covid-19 sesuai peraturan perundang-undangan yang berlaku.

Peraturan lain yang mendukung PeduliLindungi adalah

a. (Undang Undang No.36 Tahun 1999 Tentang Telekomunikasi, 1999) Pasal 7 ayat 2 jo Pasal 20 menyebutkan penyelenggaraan telekomunikasi, memperhatikan perlindungan kepentingan dan keamanan negara; perkembangan teknologi dan tuntutan global, dilakukan secara profesional dan dapat dipertanggungjawabkan dan memprioritaskan pengiriman informasi kepada negara yang menyangkut keamanan negara dan wabah penyakit.

b. (Undang Undang No.24 Tahun 2007 Tentang Penanggulangan Bencana, 2007) Pasal 3 ayat (1) huruf $h$ dalam penjelasan pasal tersebut menyebutkan bahwa ilmu pengetahuan dan teknologi harus digunakan secara optimal untuk mempermudah dan mempercepat proses penanggulangan bencana, baik pada tahap pencegahan, pada saat terjadi bencana, maupun pada tahap pasca bencana.

c. (Undang-Undang No. 36 Tahun 2009 Tentang Kesehatan, 2009) Pasal 154 ayat (2) dan (3) yang menyebutkan Pemerintah secara berkala dapat melakukan surveilans terhadap penyakit menular, dengan melakukan kerja sama dengan masyarakat negara lain.

d. (Peraturan Menteri Kesehatan No.45 Tahun 2014 Tentang Surveilans Kesehatan, 2014) Pasal 5 dan Pasal 6 dan lampiran yang menjelaskan bahwa Penyelenggaraan Surveilans Kesehatan dilakukan secara terpadu melalui pengumpulan data, pengolahan data, analisis data, dan diseminasi informasi dengan memanfaatkan sarana teknologi informasi yang mudah diakses.

e. (Undang-Undang No.6 Tahun 2018 Tentang Kekarantinaan Kesehatan, 2018). Yang dimaksud disini adalah upaya pencegahan keluar atau masuknya penyakit yang berpotensi menimbulkan kedaruratan kesehatan masyarakat. Pasal 11 (1) menyebutkan penyelenggaraan Kekarantinaan Kesehatan dilaksanakan oleh Pemerintah Pusat secara cepat, tepat, efektif dengan dukungan sumber daya, teknik operasional serta mempertimbangkan kedaulatan negara, keamanan, ekonomi, sosial, dan budaya. Selanjutnya disebutkan bahwa untuk mengurangi risiko di wilayah dilakukan Karantina Rumah, Karantina Wilayah, Karantina Rumah Sakit, atau pembatasan Sosial Berskala Besar oleh pejabat Karantina Kesehatan. (Pasal 49)

3.2 Pengaturan Perlindungan Data Pribadi dalam Teknologi Informasi dan Komunikasi

Ketentuan hukum yang mengatur perlindungan data pribadi di Indonesia, saat ini tersebar diberbagi peraturan. Belum adanya Undang-Undang Perlindungan Data Pribadi mengakibatkan tidak adanya standarisasi prinsip perlindungan data pribadi (Djafar, 2019). Meskipun demikian Pemerintah sudah memiliki Rancangan Undang-Undang Perlindungan Pribadi. Harapannya untuk segera disahkan sehingga dapat memenuhi kebutuhan masyarakat akan perlindungan data pribadi yang lebih kuat. Berkaitan dengan Aplikasi PeduliLindungi, pengaturan perlindungan data pribadi berhubungan dengan peraturan yang mengatur Teknologi Informasi dan Komunikasi, Kesehatan dan pelaksanaan Administrasi Kependudukan yaitu:

1. (Undang-Undang No. 14 Tahun 2008 Tentang Keterbukaan Informasi Publik, 2008). Disebutkan dalam Pasal 17 huruf (h) bahwa Setiap badan publik wajib membuka akses bagi setiap pemohon informasi publik kecuali informasi yang dibuka dapat mengungkap rahasia pribadi, seperti riwayat dan kondisi anggota keluarga; riwayat, kondisi dan perawatan, pengobatan kesehatan fisik, dan psikis seseorang....dan lain lain...

2. (Undang Undang No.36 Tahun 1999 Tentang. Telekomunikasi, 1999). Di dalam Pasal 40 menyebutkan adanya larangan bagi setiap orang melakukan kegiatan penyadapan atas informasi yang disalurkan melalui jaringan telekomunikasi dalam bentuk apapun. Kegiatan penyadapan disini 
dimaksudkan kegiatan memasang alat atau perangkat tambahan pada jaringan telekomunikasi untuk tujuan mendapatkan informasi dengan cara tidak sah, karena informasi yang dimiliki oleh seseorang adalah hak pribadi yang harus dilindungi. Sedangkan dalam Pasal 42 menyebutkan bahwa Penyelenggara jasa telekomunikasi wajib merahasiakan informasi yang dikirim dan atau diterima, oleh pelanggan jasa telekomunikasi melalui jaringan telekomunikasi dan atau jasa telekomunikasi yang diselenggarakannya.

3. (Undang-Undang No.19 Tahun 2016, 2016) Pasal 26 menyebutkan bahwa informasi yang menyangkut data pribadi melalui media elektronik harus dilakukan atas persetujuan orang yang bersangkutan, kecuali ditentukan lain oleh peraturan perundang-undangan

4. (Undang-Undang No. 36 Tahun 2009 Tentang Kesehatan, 2009) Pasal 57 ayat (1) menjelaskan bahwa rahasia kondisi kesehatan yang telah dikemukakan kepada penyelenggara pelayanan kesehatan merupakan hak pribadi setiap orang. Ayat (2) menjelaskan bahwa ketentuan mengenai hak atas rahasia kondisi kesehatan pribadi tidak berlaku dalam hal ...... izin yang bersangkutan; . kepentingan masyarakat; atau kepentingan orang tersebut.

5. (Peraturan Pemerintah No.71 Tahun 2019 Tentang Penyelenggaraan Sistem Dan Transaksi Elektronik, 2019). Yang dimaksud dengan penyelenggara sistem elektronik dalam peraturan pemerintah ini adalah setiap orang, penyelenggara negara, Badan Usaha, dan masyarakat yang menyediakan, mengelola, dan/atau mengoperasikan Sistem Elektronik. Dalam melakukan pemrosesan data wajib melaksanakan prinsip pelindungan Data Pribadi (Pasal 14 ayat 1) meliputi: a. ....... dilakukan secara terbatas dan spesifik dengan sepengetahuan dan persetujuan dari pemilik Data Pribadi; b..... sesuai dengan tujuannya; c..... menjamin hak pemilik Data Pribadi; d....... dilakukan secara akurat, lengkap, tidak menyesatkan....; e..... melindungi keamanan Data Pribadi dari kehilangan, penyalahgunaan....; f...... dengan memberitahukan tujuan pengumpulan, aktivitas pemrosesan......; g.... dimusnahkan dan/ atau dihapus kecuali masih dalam masa retensi sesuai dengan kebutuhan berdasarkan ketentuan peraturan perundang-undangan. Pada dasarnya pemrosesan Data Pribadi harus memenuhi ketentuan adanya persetujuan yang sah dari pemilik Data tersebut. (Pasal 14 ayat 3). Yang dimaksudkan disini adalah persetujuan yang disampaikan secara eksplisit, tidak boleh secara tersembunyi atau atas dasar kekhilafan, kelalaian, atau paksaan. Selain persetujuan, Pasal 14 ayat (4) menjelaskan bahwa pemrosesan data pribadi harus memenuhi ketentuan yang diperlukan untuk: a. pemenuhan kewajiban perjanjian dalam hal pemilik Data Pribadi merupakan salah satu pihak......b. pemenuhan kewajiban hukum dari pengendali Data Pribadi.....c. pemenuhan pelindungan kepentingan yang sah (vital interest), atau melindungi hal yang sangat penting tentang keberadaan seseorang pemilik
Data Pribadi, d. pelaksanaan kewenangan pengendali Data Pribadi.....e. Pemenuhan kewajiban pengendali Data Pribadi dalam pelayanan publik untuk kepentingan umum dan/atau pemenuhan kepentingan yang sah lainnya dari pengendali Data Pribadi dan/atau pemilik Data Pribadi.

6. (Peraturan Menteri Komunikasi Dan Informatika No. 20 Tahun 2016 Tentang Perlindungan Data Pribadi Dalam Sistem Elektronik, 2016), Pasal 9 menyebutkan bahwa perolehan dan pengumpulan Data Pribadi oleh Penyelenggara Sistem Elektronik wajib berdasarkan persetujuan atau berdasarkan ketentuan peraturan perundang-undangan. Sebelumnya dalam Pasal 1 menjelaskan bahwa yang dimaksud persetujuan adalah pernyataan secara tertulis baik secara manual dan/atau elektronik yang diberikan oleh Pemilik Data Pribadi setelah mendapat penjelasan secara lengkap mengenai tindakan perolehan, pengumpulan, pengolahan, penganalisaan. penyimpanan, penampilan, pengumuman, pengiriman, dan penyebarluasan serta kerahasiaan atau ketidakrahasiaan Data Pribadi. Selanjutnya dalam Pasal 6, dijelaskan bahwa Penyelenggara Sistem Elektronik harus menyediakan formulir persetujuan dalam bahasa Indonesia. Sedangkan pemusnahan Data Pribadi dalam Sistem Elektronik harus sesuai dengan ketentuan Peraturan Menteri ini atau peraturan perundang-undangan yang berlaku. (Pasal 25).

7. (Peraturan Pemerintah No.40 Tahun 2019 Tentang Pelaksanaan Administrasi Kependudukan, 2019), Pasal 58 menjelaskan adanya larangan bagi Kementerian/lembaga dan badan hukum Indonesia yang memperoleh Data Pribadi Penduduk atau Data Kependudukan dalam a. menggunakan Data Pribadi Penduduk atau Data Kependudukan melampaui batas kewenangannya. Yang dimaksud disini adalah menggunakan untuk kepentingan pribadi atau kepentingan lain yang tidak sesuai dengan tujuan pemberian kewenangan sebagaimana diatur dalam ketentuan peraturan perundangundanganatau, b. menjadikan Data Pribadi Penduduk atau Data Kependudukan sebagai bahan informasi publik sebelum mendapat persetujuan dari Menteri.

\subsection{Pelaksanaan Perlindungan Data Pribadi Peduli Lindung}

Indonesia merupakan pasar yang menarik bagi produsen smartphone, berdasarkan (https://databoks.katadata.co.id/, 2020) ada 56,2\% yang telah menggunakan ponsel pintar pada 2018. Di tahun 2019 masyarakat yang menggunakan ponsel ponsel pintar meningkat menjadi 63,3\%. Dari sejumlah pengguna smartphone tersebut. Menurut (Menkominfo) Johnny G. Plate total pengguna Aplikasi PeduliLindungi sampai bulan Juni 2020 sudah mencapai 4.025.861 jiwa atau sekitar 5 persen dari total pengguna smartphone Indonesia. Target pengguna adalah 25 persen dari total 
pengguna smartphone di Indonesia, yakni sebanyak 78 juta pengguna. Saat ini rating aplikasi PeduliLindungi adalah 4.4 memiliki rating yang cukup baik, termasuk dalam kategori disukai oleh pengguna.(Bisnis.com, 2020). Aplikasi PeduliLindungi juga diintegrasikan dengan aplikasi ride-hailing Gojek sehingga PeduliLindungi dapat diakses melalui aplikasi gojek. Integrasi ini bertujuan untuk mendorong penggunaan PeduliLindungi yang saat ini baru diunduh 4,1 juta kali.(C. Indonesia, 2020)

PeduliLindungi dikelola oleh PT Telekomunikasi Indonesia dan terintegrasi dengan data center dalam negeri sehingga aman bagi pengguna. Pada saat pengguna melakukan registrasi pada PeduliLindungi, maka data yang disimpan No.HP dan lokasi serta waktu saat terjadi pertukaran data. Data ini bersifat rahasia. Data-data yang diambil dan disimpan di dalam ponsel pengguna berupa: $(\mathrm{K}$. K. Informatika, 2020)

a. MAC address pengguna yang terekam oleh pengguna PeduliLindungi lainnya yang sama-sama mengaktifkan bluetooth.

b. User ID pengguna yang didapat ketika registrasi. c. Lokasi pengguna pada saat terjadi pertukaran data

d. Waktu pada saat kontak terjadi

e. Durasi selama kontak terjadi.

PeduliLindungi tidak mengambil data daftar kontak yang terdapat di HP pengguna. Data-data tersebut disimpan secara terenkripsi di server PeduliLindungi yang aman dan tidak dibagikan ke publik, kecuali kepada instansi pemerintah yang saat ini ditunjuk dalam menangani pandemi COVID-19, atau karena ketentuan hukum. Data pengguna hanya akan diakses bila pengguna dalam risiko tertular COVID-19 dan perlu segera dihubungi oleh petugas kesehatan. Pengguna sepenuhnya mengendalikan data dan dapat sewaktu-waktu dapat mencabut persetujuan perekaman data dengan mengirimkan email ke PeduliLindungi@kominfo.go.id. Aplikasi tidak dapat mengambil dan membagikan data tanpa persetujuan pengguna PeduliLindungi. Jika pandemi berakhir maka PeduliLindungi akan menghapus seluruh data pengguna. Data kontak bluetooth yang tersimpan di penyimpanan lokal ponsel pengguna akan dihapus secara berkala setelah data dikirim ke server setiap hari. Jika pengguna menghapus aplikasi maka datapun akan ikut terhapus. Atau penghapusan data di server melalui email ke PeduliLindungi@kominfo.go.id.

Untuk melindungi data pribadi pengguna Aplikasi ini, Menteri Komunikasi dan Informasi (Menkominfo) bekerja sama dengan Badan Siber dan Sandi Negara (BSSN) untuk memastikan aplikasi pelacak kontak Covid-19 PeduliLindungi telah memenuhi prinsip perlindungan data pribadi dan keamanan. BSSN sudah melakukan pengecekan keamanan aplikasi yang disebut IT Security Assesment, termasuk versi terbaru PeduliLindungi, namun tetap harus dimonitor dan assessment secara berkala. (Cyberthreat.id, 2020). Di awal munculnya PeduliLindungi banyak pihak yang meragukan tentang perlindungan data pribadi pengguna aplikasi ini. Kementerian Kominfo melakukan Siaran Pers pada tanggal 17 April Tahun 2020 (No. $57 / \mathrm{Hm} /$ Kominfo/04/2020) yang isinya menjamin keamanan Aplikasi PeduliLindungi dari Phising dan Malware.

Meskipun sudah ada jaminan keamanan dari Pemerintah, Peneliti Communication and Information System Security Research Center (CISSRec) berpendapat bahwa masih diperlukan audit forensik digital. Menurutnya kondisi keamanan siber Indonesia memang masih relatif memprihatinkan. Pada 2019, tercatat ada 88 juta serangan terhadap sistem keamanan di Indonesia, karena itu Undang-Undang Perlindungan Data Pribadi harus segera disahkan agar dapat digunakan untuk memaksa perusahaan atau penyedia layanan di Indonesia melakukan proteksi data pengguna dengan serius. Sebelum adanya pengesahan Undang-Undang yang terpenting adalah semua pihak yang berkepentingan mentaati peraturan -peraturan yang ada.

\section{Kesimpulan}

Penggunaan teknologi digital pada masa sekarang sudah merupakan kebutuhan untuk melakukan suatu kegiatan diberbagai bidang kehidupan. Terlebih adanya pandemi Covid-19, yang mengharuskan adanya pembatasan sosial. Penyebaran covid-19 yang begitu cepat, dan masif mengharuskan pemerintah dengan berbagai upaya untuk mengurangi penyebaran tersebut. Diantaranya adalah dengan meluncurkan Aplikasi PeduliLindungi lewat Kementrian Komunikasi dan Informatika yang bekerjasama dengan PT Telkom Tbk. Aplikasi PeduliLindungi ini dikembangkan pemerintah untuk membantu instansi terkait dalam melakukan pelacakan untuk menghentikan penyebaran Covid19. Perlindungan Data Pribadi pengguna Aplikasi PeduliLindungi didasarkan pada peraturan peraturan di bidang Teknologi Informasi dan Komunikasi, Kesehatan dan pelaksanaan Administrasi Kependudukan karena memang belum ada Undangundang yang khusus mengatur Perlindungan Data Pribadi. Meskipun ada jaminan keamanan data pribadi bagi pengguna PeduliLindungi sampai sekarang pengguna PeduliLindungi masih jauh dari harapan. Tentunya perlu penelitian lebih lanjut untuk mengetahui kurangnya minat masyarakat terhadap Aplikasi PeduliLindungi ini.

\section{Referensi}

Bisnis.com. (2020). Aplikasi PeduliLindungi Masih Sepi Peminat. Bisnis.Com. 
https://teknologi.bisnis.com/read/20200630/84 /1259752/aplikasi-PeduliLindungimasih-sepipeminat

Cyberthreat.id. (2020). No Title. https://cyberthreat.id/read/7325/Ini-HasilEvaluasi-BSSN-terhadap-Aplikasi-Covid-19PeduliLindungi

Dewi, S. (2016). Konsep Perlindungan Hukum Atas Privasi Dan data Pribadi Dikaitkan Dengan Penggunaan Cloud Computing Di Indonesia. Yustisia, $5(1)$. https://jurnal.uns.ac.id/yustisia/article/view/87 $12 / 7802$

Djafar, W. (2019). Hukum Pelindungan Data Pribadi di Indonesia:Lanskap, Urgensi dan Kebutuhan Pembaruan. https://law.ugm.ac.id/wpcontent/uploads/sites/1043/2019/08/Hukum-

Perlindungan-Data-Pribadi-di-IndonesiaWahyudi-Djafar.pdf

Europe, E. U. A. for F. R. and C. of. (2014). Handbook on European Data Protection Law, .

https://databoks.katadata.co.id/. (2020). Penetrasi Ponsel Pintar di Indonesia. Pengguna Smartphone Diperkirakan Mencapai 89\% Populasi Pada 2025. https://databoks.katadata.co.id/datapublish/202 0/09/15/pengguna-smartphone-diperkirakanmencapai-89-populasi-pada-2025

Indonesia, C. (2020). Rebut Jutaan Pengguna, Aplikasi PeduliLindungi Gandeng Gojek. Cnnindonesia.Com.

https://www.cnnindonesia.com/teknologi/2020 0630210648-185-519279/rebut-jutaanpengguna-aplikasi-PeduliLindungi-gandenggojek

Informatika, K. K. (2020). Persayaratan dan Ketentuan. PeduliLindungi.Id. https://PeduliLindungi.id/syarat-ketentuan

Keputusan Menteri Komunikasi Dan Informatika No. 171 Tahun 2020 Tentang Penetapan Aplikasi PeduliLindungi dalam Rangka Pelaksanaan Surveilans Kesehatan Penanganan Covid-19, (2020).

Keputusan Menteri Komunikasi dan Informatika No.159 Tahun 2020 Tentang Upaya Penanganan Corona Virus Disease (COVID-1 9) Melalui Dukungan Sektor Pos Dan Informatika, (2020).

Kompas, L. (2020). Vakum Regulasi Aplikasi Pelacak Covid-19 di Indonesia. Kompas.Com. https://kompas.id/baca/humaniora/kesehatan/2 020/03/29/vakum-regulasi-aplikasi-pelacakcovid-19-diindonesia/?_t=sIFkSkDbBPvEui33hzbwsZLC 4Mjqyl7UrQE2O0lf1ZTtqOLt0C2CGthSFtg
Maulana, I. (2020). Webminar Aspek Hukum Pemanfaatan TIK Dalam Memutus Mata Rantai Penularan Covid-19. https://us02web.zoom.us/j/663272947/pwd=K zlJMDNpYXVaVWImazMxMW9tQ010UT09

Peraturan Pemerintah No.40 Tahun2019 tentang Pelaksanaan Administrasi Kependudukan, (2019).

Peraturan Pemerintah No.71 Tahun 2019 tentang Penyelenggaraan Sistem dan Transaksi Elektronik, (2019).

Peraturan Menteri Komunikasi Dan Informatika No. 20 tahun 2016 tentang Perlindungan Data Pribadi dalam Sistem Elektronik, (2016).

Peraturan Menteri Kesehatan No.45 Tahun 2014 tentang Surveilans Kesehatan, (2014)

Rosadi, S. D. (2018). Perlindungan Pivasi dan Data Pribadi Dalam Era Ekonomi Digital Di Indonesia. Yustisia, $4(1)$. http://journal.unpar.ac.id/index.php/veritas/arti cle/download/2916/2507

Sumitra, I. D. (2020). Webminar The 3rd International Conference of Informatics, Engineering, Science and Technology (INCITEST).

https://www.youtube.com/watch?v=Kp3xzdN $\mathrm{W} 8 \mathrm{tU}$

Undang Undang No.36 Tahun 1999 tentang Telekomunikasi, (1999).

UndangUndang No.24 Tahun 2007 tentang Penanggulangan Bencana, (2007).

Undang-Undang No. 14 Tahun 2008 Tentang Keterbukaan Informasi Publik, (2008).

Undang-Undang No. 36 Tahun 2009 tentang Kesehatan, (2009).

Undang-Undang No.6 Tahun2018 tentang Kekarantinaan Kesehatan, (2018).

Undang-Undang No.19 Tahun 2016, Pub. L. No. Perubahan No.11 Tahun 2008 TentangInformasi Dan Transaksi Elektronik (2016).

Undang-Undang No. 39 Tahun 1999 Tentang Hak Asasi Manusia, (1999). 